\title{
The Evaluation of an Online English Course for Tourism Workers in Ninh Binh from Learners' Perspective
}

\author{
Đặng Thanh Điềm ${ }^{1} \square$ Mai Thị Thu Hân ${ }^{2}$, Nguyễn Thị Huệ ${ }^{3}$, Nguyễn Thị Lệ Thu ${ }^{4}$ and Nguyễn Thị Liên ${ }^{5}$ \\ ${ }^{12345}$ MA, English Teacher, Department of Foreign Languages and Information Technology, Hoa Lu University, Ninh Binh \\ Province, Vietnam
}

$\square$ Corresponding Author: Đặng Thanh Điềm, E-mail: dtdiem@hluv.edu.vn

\begin{tabular}{|c|c|}
\hline ARTICLE INFORMATION & ABSTRACT \\
\hline Received: 04 September 2021 & \multirow{6}{*}{$\begin{array}{l}\text { This article presents the results of a study designed to measure the evaluation of } \\
\text { learners on an online English course. A survey questionnaire was distributed to 20- } \\
\text { course attendees, who are tourism workers in Ninh Binh province. The results of the } \\
\text { survey reveal learners' positive attitudes towards (1) the course content, (2) the course } \\
\text { approach, (3) the course materials, (4) the course management, and (5) the perceived } \\
\text { course outcomes. Besides, semi-structured interviews were carried out to pinpoint the } \\
\text { difficulties learners encountered throughout the course. Based on the preliminary } \\
\text { analyses of this questionnaire form, suggestions for a more efficient application of this } \\
\text { online course are proposed. }\end{array}$} \\
\hline Accepted: 25 October 2021 & \\
\hline Published: 31 October 2021 & \\
\hline DOI: 10.32996/jeltal.2021.3.11.6 & \\
\hline KEYWORDS & \\
\hline $\begin{array}{l}\text { Course evaluation, online course, } \\
\text { tourism workers }\end{array}$ & \\
\hline
\end{tabular}

\section{Introduction}

Flexible options in education have become more available recently thanks to technological advancement and innovation, especially in the industry 4.0 era. E-learning is considered a viable solution for effective life-long education for sustainable development in a population of learners who are simultaneously full-time employees (Nguyen et al., 2020). E-learning has shown a great prospect for application by virtue of its aforementioned flexibility and convenience regardless of time and place. It has become a powerful form, especially in the occurrence of coronavirus pandemics across the whole world.

As a labor-intensive service industry, tourism's growth depends much on the availability of good-quality personnel to deliver, operate and manage the service (Amoah \& Baum, 1997). E-learning has fulfilled the need for an alternative approach to satisfy the constant requirement of training and retraining the industry's staff. E-learning environment has been proved to cater to a wide range and academic and employability skills that reflect the complexity of the tourism and hospitality industry (Abdon $\&$ Ninominya, 2007).

To our best of understanding, so far there has not been much research on tourism E-learning programs to support the training of human tourism resources. The study addresses the evaluation of an online English course specially designed for tourism workers in Ninh Binh province from the learners' perspective.

The aim of the study can be clarified as follows:

1) To measure the evaluation of learners in the course (in terms of course content, course, course approach, the course materials, course management, and perceived course outcomes)

2) To investigate the difficulty learners encountered during the course

\section{Literature Review}

\subsection{E-learning}

E-learning has been long believed to be a subset of the larger worlds of both "information technology" and "education and training" (Sun Microsystems Association, 2007). It addresses learning activity, which is proceeded via electronic technology (Servage, 2005). According to Condie (2007), E-learning is a systematic utilization of networked multimedia computer technologies

Copyright: (C) 2021 the Author(s). This article is an open access article distributed under the terms and conditions of the Creative Commons Attribution (CC-BY) 4.0 license (https://creativecommons.org/licenses/by/4.0/). Published by Al-Kindi Centre for Research and Development, London, United Kingdom. 
to empower learners, improve learning, connect learners to people and resources supportive of their needs, integrate learning with performance, and familiarize the individual with the organizational goal.

\subsection{E-learning in tourism education}

E-learning has become an important part of the worldwide education agenda in general, and in the tourism industry in particular. Since the beginning of the twenty-first century, online learning and teaching in the fields of hospitality, leisure, sport, and tourism were in their introductory phase (Lominé, 2002). Eraqui et al. (2011) summarize a number of researchers' ideas about the utilization of new technologies to facilitate the process of learning and the flow of information in many hospitality and tourism institutions. Sigala (2020) supposes that E-learning is to familiarize learners and not only make them more competent in knowledge but also develop their information literacy and knowledge management skills.

Penfold (2008) comments that educators in hospitality and tourism education should be encouraged to use methods that stimulate the development of personal and intellectual skills and develop students' critical thinking capabilities. In-service education programming at all levels in the services sector has been in great demand for years Hsu (2020). Eraqi et al. (2011) insist that more involvement of the hospitality learners in their own learning should be encouraged and student-centered teaching and learning approaches should be increased.

This study discusses the learners' satisfaction in an online English course for tourism workers in Ninh Binh province. The course is designed for full-time in-service staff.

\subsection{Learners' evaluation of online course}

Course satisfaction is attitudes and feelings regarding the experience and outcomes in a course. There are a number of criteria learners base on to evaluate the course that they take online. Sun et al. (2008) review factors that are critical to the activities of and affecting learners' satisfaction with E-learning. The six main components are learners, instructor, course, technology, design, and environment. Qteishat (2013) also considers contributing elements to students' attitudes towards E-learning in higher education. Their model suggests the following factors: (1) Perceived usefulness; (2) Perceived ease of use; (3) Technical Support and (4) Previous experience.

Mohammadi (2015) proposes different attributes to explore user satisfaction when using an E-learning system, including education quality, service quality, technical system quality, information and content quality, perceived ease of use, and perceived usefulness.

This study exploits the aforementioned discussions to build up a framework of five criteria for learners to assess the success of their online English course participation, including (1) the course content, (2) the course approach, (3) the course materials, (4) the course management, and (5) the perceived course outcomes.

\section{Methods}

\subsection{Study context}

The study is conducted in Ninh Binh, a small province to the south of Hanoi Capital, which possesses enormous potential for the tourism sector with numerous natural, historical and cultural heritages. Despite this favorable condition for development, Ninh Binh's tourism has been considered to be underdeveloped compared to its potential. It is on an account of several reasons, one of which is the human tourism resource. According to the report by Ninh Binh People's Committee, the labor force in this industry has been insufficient both in quantity and in quality. The province's tourism sector has been in burgeoning demand for training and improving English communication competence for its staff.

English proficiency of the local tourism staff has been received greater concern and investment from leaders and policymakers of Ninh Binh. A CLS online course for tourism workers is one out of the two anticipated outcomes of a two-year project ordered by the Ninh Binh Tourism Department and implemented by Hoa Lu University. The online course involved the participation of workers from many tourism enterprises in Ninh Binh. Learners of the course completed online lessons attended online web meetings and took part in offline on-site meetings. The knowledge of general English, English for presentations of the tourism destinations as well as English for occupational practices are provided throughout the course.

\subsection{Participants}

Learners of the course are full-time tourism workers performing different tasks at the boat station ( 2 participants), in the ticket office ( 2 participants), at the restaurants (6 participants), at the hotels (10 participants).

The study does not examine the influence of participants' gender, age, marital status, educational and professional experience on their evaluation of the online course. That is why information related to these aspects is not mentioned in the article. 


\subsection{Questionnaires}

All evaluation criteria are measured by a 5-level Likert scale as follows.
1 - strongly disagree
2 - disagree
3 - partly agree
4 - agree
$\mathbf{5}$ - strongly agree

The questionnaire form is designed in five main parts: (1) The evaluation of the course content; (2) The evaluation of the course approach; (3) The evaluation of the course materials; (4) The evaluation of the course management and (5) The perceived course outcomes.

Table 1: The questionnaire

\begin{tabular}{|c|c|c|c|c|c|c|}
\hline \multicolumn{2}{|c|}{ Part 1: The evaluation of the course content } & \multirow{2}{*}{1} & \multirow{2}{*}{2} & \multirow{2}{*}{$\begin{array}{l}3 \\
\square\end{array}$} & \multirow{2}{*}{$\begin{array}{l}4 \\
\square\end{array}$} & \multirow{2}{*}{5} \\
\hline 1.1 & I can see the clear objectives of each unit. & & & & & \\
\hline 1.2 & The content of each unit is suitable for me. & $\square$ & $\square$ & $\square$ & $\square$ & $\square$ \\
\hline 1.3 & The distribution between theory and practice is proper. & $\square$ & $\square$ & $\square$ & $\square$ & $\square$ \\
\hline 1.4 & The course content is relevant to what I am working on. & $\square$ & $\square$ & $\square$ & $\square$ & $\square$ \\
\hline 1.5 & The course content is accurate, logical, and focused. & $\square$ & $\square$ & $\square$ & $\square$ & $\square$ \\
\hline 1.6 & The course content is extensive and up-to-date. & $\square$ & $\square$ & $\square$ & $\square$ & $\square$ \\
\hline \multicolumn{2}{|c|}{ Part 2: The evaluation of the course approach } & 1 & 2 & 3 & 4 & 5 \\
\hline 2.1 & The instructions are clear. & $\square$ & $\square$ & $\square$ & $\square$ & $\square$ \\
\hline 2.2 & Learning activities are relevant to what I am working on. & $\square$ & $\square$ & $\square$ & $\square$ & $\square$ \\
\hline 2.3 & The learning activities are vivid and motivating. & $\square$ & $\square$ & $\square$ & $\square$ & $\square$ \\
\hline 2.4 & The course takes full use of assistive learning devices. & $\square$ & $\square$ & $\square$ & $\square$ & $\square$ \\
\hline 2.5 & $\begin{array}{l}\text { The course duration is proper to achieve the course objectives and to } \\
\text { deliver the course content. }\end{array}$ & $\square$ & $\square$ & $\square$ & $\square$ & $\square$ \\
\hline 2.6 & $\begin{array}{l}\text { I can exchange information and knowledge easily and quickly with other } \\
\text { learners. }\end{array}$ & $\square$ & $\square$ & $\square$ & $\square$ & $\square$ \\
\hline \multicolumn{2}{|r|}{ Part 3: The evaluation of the course materials } & 1 & 2 & 3 & 4 & 5 \\
\hline 3.1 & The course materials are compatible with the course content. & $\square$ & $\square$ & $\square$ & $\square$ & $\square$ \\
\hline 3.2 & The course materials are beautifully designed and motivating. & $\square$ & $\square$ & $\square$ & $\square$ & $\square$ \\
\hline 3.3 & The course materials are suitable for online learning. & $\square$ & $\square$ & $\square$ & $\square$ & $\square$ \\
\hline 3.4 & The course materials are extensive and relevant to real working situations. & $\square$ & $\square$ & $\square$ & $\square$ & $\square$ \\
\hline 3.5 & The website satisfies the learners' needs. & $\square$ & $\square$ & $\square$ & $\square$ & $\square$ \\
\hline 3.6 & The website is beautifully designed and user-friendly. & $\square$ & $\square$ & $\square$ & $\square$ & $\square$ \\
\hline \multicolumn{2}{|c|}{ Part 4: The evaluation of the course management } & 1 & 2 & 3 & 4 & 5 \\
\hline 4.1 & The course schedule is suitable. & $\square$ & $\square$ & $\square$ & $\square$ & $\square$ \\
\hline 4.2 & Online lessons create great flexibility. & $\square$ & $\square$ & $\square$ & $\square$ & $\square$ \\
\hline 4.3 & I can get useful support from the course instructors. & $\square$ & $\square$ & $\square$ & $\square$ & $\square$ \\
\hline \multicolumn{2}{|c|}{ Part 5: The perceived course outcomes } & 1 & 2 & 3 & 4 & 5 \\
\hline 5.1 & I can improve my English proficiency. & $\square$ & $\square$ & $\square$ & $\square$ & $\square$ \\
\hline 5.2 & I can improve my working performance. & $\square$ & $\square$ & $\square$ & $\square$ & $\square$ \\
\hline 5.3 & I can enhance my critical thinking and self-study skills. & $\square$ & $\square$ & $\square$ & $\square$ & $\square$ \\
\hline 5.4 & I feel more confident when using English at work. & $\square$ & $\square$ & $\square$ & $\square$ & $\square$ \\
\hline 5.5 & I feel satisfied with the course quality. & $\square$ & $\square$ & $\square$ & $\square$ & $\square$ \\
\hline
\end{tabular}

The questionnaire responses were analyzed via SPSS version 20 to figure out how learners assess their experience taking part in the course.

\subsection{Semi-structured interviews}

The study also exploits the strengths of semi-structured interviews to investigate learners' troubles regarding their participation during the course online. The main question is "What are the difficulties you encountered when taking part in the course?", while other questions related to the questionnaire would also be included (if the interviewees mentioned them). 


\section{Results and Discussion}

\subsection{Learners' evaluation of the online English course}

Learners' responses from the survey questionnaire were analyzed in SPSS software to infer their assessment of the course. In each table of analyses, $\mathbf{N}$ is the number of responses; Minimum and Maximum represent respectively the smallest and highest points that respondents gave for each question. Mean figures inform the average scores of the respondents' choices. Higher Mean scores reveal that learners agree with the statements to a larger extent. Standard Deviation demonstrates the dispersion of the dataset, in which the more the data spread out, the higher the standard deviation is.

\subsubsection{The evaluation of the course content}

There are six statements involved in the assessment of the course content. All the mean scores of the questions are higher than 3 , which means in general the respondents agree with each idea. As the standard deviation of the statement "The course content is relevant to what I am working on" is smaller than 0.5 , learners mostly agree and strongly agree that the contents of units are relevant to their real working scenarios. However, when it comes to the originality of the content, learners' answers are quite different. Although the Mean score is 4.45 (more than agree), there are still respondents who supposed that the course content is not extensive and up-to-date enough.

Table 2: The evaluation of the course content

\begin{tabular}{llllll}
\hline & $\mathrm{N}$ & Minimum & Maximum & Mean & Std. Deviation \\
\hline I can see the clear objectives of each unit. & 20 & 3 & 5 & 4.40 & .663 \\
\hline The content of each unit is suitable for me. & 20 & 2 & 5 & 4.00 & .894 \\
\hline The distribution between theory and practice is proper. & 20 & 2 & 5 & 4.15 & .831 \\
\hline The course content is relevant to what I am working on. & 20 & 4 & 5 & 4.35 & .477 \\
\hline The course content is accurate, logical, and focused. & 20 & 3 & 5 & 3.95 & .589 \\
\hline The course content is extensive and up-to-date. & 20 & 1 & 5 & 4.45 & .548 \\
\hline Valid N (listwise) & 20 & & & & \\
\hline
\end{tabular}

\subsubsection{The evaluation of the course approach}

The course approach involves clear instructions, relevant activities, vivid and motivating activities, proper course duration, the usefulness of the assistive learning devices, and the interaction among learners.

Table 3: The evaluation of the course approach

\begin{tabular}{|c|c|c|c|c|c|}
\hline & $\mathrm{N}$ & Minimum & Maximum & Mean & Std. Deviation \\
\hline The instructions are clear. & 20 & 3 & 5 & 4.00 & .548 \\
\hline Learning activities are relevant to what I am working on. & 20 & 4 & 5 & 4.40 & .497 \\
\hline The learning activities are vivid and motivating. & 20 & 2 & 5 & 4.05 & .921 \\
\hline The course takes full use of assistive learning devices. & 20 & 3 & 5 & 4.20 & .812 \\
\hline $\begin{array}{l}\text { The course duration is proper to achieve the cours } \\
\text { objectives and to deliver the course content. }\end{array}$ & 20 & 2 & 5 & 3.90 & .831 \\
\hline $\begin{array}{l}\text { can exchange information and knowledge easily anc } \\
\text { quickly with other learners. }\end{array}$ & 20 & 2 & 5 & 4.10 & 1.091 \\
\hline Valid N (listwise) & 20 & & & & \\
\hline
\end{tabular}

Among these sub-criteria, the relevance of the learning activities during the course is highly appreciated by the learners. On the other hand, they wonder about the duration of the course. Actually, in the interviews, some learners said that the schedule of learning was too tight for them. They sometimes failed to complete the lessons on time.

\subsubsection{The evaluation of the course materials}

The course materials include videos, audio, pictures, and images, as well as the files from a book written by the course instructors. Learners can easily access these materials during the course. From the survey, it can be seen that learners have a high opinion of the course materials. They all agree that the course materials are compatible with the course content and are beautifully designed. These materials are suitable for online learning and help motivate learners a great deal. Moreover, they are relevant to the real working situations of the learners with resourceful features. With regard to the website, learners agree that the website is beautifully designed and user-friendly and it can satisfy their needs of learning. 
Table 4: The evaluation of the course materials

\begin{tabular}{|c|c|c|c|c|c|}
\hline & $\mathrm{N}$ & Minimum & Maximum & Mean & Std. Deviation \\
\hline $\begin{array}{l}\text { The course materials are compatible with the course } \\
\text { content. }\end{array}$ & 20 & 2 & 5 & 4.15 & .910 \\
\hline $\begin{array}{l}\text { The course materials are beautifully designed anc } \\
\text { motivating. }\end{array}$ & 20 & 3 & 5 & 4.35 & .853 \\
\hline The course materials are suitable for online learning. & 20 & 3 & 5 & 4.60 & .583 \\
\hline $\begin{array}{l}\text { The course materials are extensive and relevant to rea } \\
\text { working situations. }\end{array}$ & 20 & 3 & 5 & 4.50 & .671 \\
\hline The website satisfies the learners' needs. & 20 & 2 & 5 & 4.15 & .792 \\
\hline The website is beautifully designed and user-friendly. & 20 & 3 & 5 & 4.25 & .698 \\
\hline Valid N (listwise) & 20 & & & & \\
\hline
\end{tabular}

\subsubsection{The evaluation of the course management}

When delivering the course, the course instructors provided a schedule of releasing units and lessons. Every three days, new lessons were opened for learners. Although there was no limitation of the time when the lessons were due, the learners had to face the pressure of completing the previous lessons when the next was coming out. That may be the reason why many learners reported that the course schedule is not really suitable for their learning pace. Sometimes, they would fail to complete the lessons as scheduled and had to deal with the workload at the end of the course.

As for other criteria, learners are of the high opinion that the course going online creates a great deal of flexibility in terms of time and place to access and complete the lessons. Moreover, they can get constant and useful support from the course instructors.

Table 5: The evaluation of the course management

\begin{tabular}{llllll}
\hline & $\mathrm{N}$ & Minimum & Maximum & Mean & Std. Deviation \\
\hline The course schedule is suitable. & 20 & 2 & 5 & 2.90 & .865 \\
\hline Online lessons create great flexibility. & 20 & 4 & 5 & 4.80 & .400 \\
\hline I can get useful support from the course instructors. & 20 & 4 & 5 & 4.75 & .433 \\
\hline Valid N (listwise) & 20 & & & \\
\hline
\end{tabular}

\subsubsection{Learners' perceived course outcomes}

Regarding the expected course outcomes, learners suppose that there would be improvement in their oral English communication skills with more accurate pronunciation (that they learned a lot from the model videos and sample practices), more sufficient vocabulary range, better presentation skills, richer knowledge of highly context-based English language suitable to their distinctive working requirements and more professional occupational skills. Especially, learners express that they get more confident when using English at work and that is how they become satisfied with the course quality.

Table 6: The perceived course outcomes

\begin{tabular}{llllll}
\hline & $\mathrm{N}$ & Minimum & Maximum & Mean & Std. Deviation \\
\hline I can improve my English proficiency. & 20 & 2 & 5 & 3.95 & .740 \\
\hline I can improve my working performance. & 20 & 3 & 5 & 4.05 & .497 \\
\hline I can enhance my critical thinking and self-study skills. & 20 & 2 & 5 & 4.00 & .632 \\
\hline I feel more confident when using English at work. & 20 & 2 & 5 & 3.95 & .805 \\
\hline I feel satisfied with the course quality. & 20 & 4 & 5 & 4.60 & .490 \\
\hline Valid N (listwise) & 20 & & & & \\
\hline
\end{tabular}

\subsubsection{Learning difficulties}

Afifi (2011) summarizes the barriers of participating in the online course from the learners' perspective as follows: (1) Lack of an IT infrastructure; (2) Reduced social and cultural interaction; (3) Lack of management encouragement and (4) Technical problems. Additionally, there is a list of expected disadvantages when applying E-learning in higher education.

Table 7: Potential disadvantages of applying E-learning in Egyptian tourism colleges 


\begin{tabular}{llr}
\hline No. & Potential disadvantages of applying e-learning & $\%$ \\
\hline 1. & Lack of interaction inherent in e-learning & 71.4 \\
2. & Consuming time in preparation & 64.3 \\
3. & Affecting negatively on the courses' practical application & 42.9 \\
4. & Students' immaturity and lack of self-discipline & 21.4 \\
5. & Staff members are not prepared yet for e-learning requirements & 21.4 \\
6. & Facing technical problems & 14.3 \\
\hline
\end{tabular}

(Afifi, 2011)

The results of the interview report the similar troubles that learners encountered during the course. Despite some benefits of the online course such as increasing the professional knowledge, increasing the ability for access from anywhere/anytime, enabling students to learn at their own pace, or improving IT skills for learners, they met several major problems.

Firstly, they feel in lack of vivid interaction with peers and course instructors. Learners really longed for constant contact with others during the course to discuss their problems. They highly appreciated that course instructors gave instant feedback on their work and that the instructors chose the high-quality products/assignment among the learners to share and recognize in the class group. In their mind, thanks to these actions, they felt the course more lively and "real".

Another difficulty that learners confront during the online course is the technical problems. They reported the troubles uploading files of assignments on the website, or moving to the next lesson. To be specific, learners found difficulties in loading the course on mobiles, as the interface on the computer is more user-friendly. Because of some default settings on the website, learners had more questions at the beginning of the course than towards the end of the course when they got familiar with the web.

A major factor hindering the learners from gaining the best results in the course is related to their self-discipline and time management skills. Learners selected their own time to complete the lessons on the website, following the course schedule. Although the course instructors sent reminders to learners, it was the learners themselves who decided when to study. When they failed to follow the schedule, there would be a load of work waiting for them at a time. That is why time management skills, as well as self-discipline, are essential if learners want to obtain the course benefits to the fullest.

\section{Conclusion}

Measuring the learners' evaluation of the online English course for tourism workers in Ninh Binh is important to promote the course quality. This study identifies how learners assess the course in terms of five criteria, including the course content, the course approach, the course materials, the course management, and the perceived course outcomes.

In general, learners highly appreciate the course content, especially its relevance to their professional practice. The course approach is reported to be suitable and flexible; the course materials are beautifully designed and captivating. Learners all perceive the positive outcomes from the course with their better performance in the language and in the profession (both general and functional English). Regarding course management, learners opine that the course schedule is too tight and they need more time for each lesson. Moreover, more interaction between learners and course instructors is welcomed.

The difficulties learners face during the course online include the lack of face-to-face communication with other learners and course instructors, the technical problems in exploiting the website, and the high requirement for self-discipline and time management skills. If learners can develop the necessary skills, they can make full use of the online course to improve their communicative competence in English.

\section{Recommendations for further application of the course}

Quang et al. (2020) reflect on how the Covid-19 pandemic illustrates the need for proactive efforts to prepare readiness strategies and draw up initiatives for the long-term development of tourism in Vietnam. Among these policies, one of the human-resourcespecific policies proposed by Quang et al. is to fund human resources training and help industry-related training institutions effectively move their operations online. The provision of re-training programs is a contributing factor to improving workers' skillsets and their labor productivity according to Vietnam Tourism Occupational Standards (MCST, 2020).

Online courses to improve English communication competence, designed specifically for tourism workers in Ninh Binh, can be one of the useful parts of the training and re-training programs in the tourism sector of the province. In order to bring the course to practice on a larger scale, learners need to satisfy a number of criteria and possess several skills to have a successful deployment of the online course, including self-motivation, IT skills, time management, and self-discipline. At the same time, the course 
instructors also play a vital role in the effectiveness and success of this E-learning-based course. Accordingly, the instructors should have IT competency, practical style, attitude, and mindset (Eraqui et al., 2011)

\section{References}

[1] Abdon, B. R. \& Ninominya, S. (2007). E-learning in higher education makes its debut in Cambodia: Thee provincial business education project. International Review of research in open and distance learning, 8(1), DOI: 10.19173/irrodl.v8i1.333

[2] Afifi, G. M. H. (2011). E-learning as an alternative strategy for tourism higher education in Egypt. Quality Assurance in Education, 19(4), 357374. doi:10.1108/0968488111117007

[3] Amoah, V.A. and Baum, T. (1997), "Tourism education: policy versus practice ", International Journal of Contemporary Hospitality Management, 9(1), 5-12. https://doi.org/10.1108/09596119710157531

[4] Condie, R., \& Livingston, K. (2007). Blending online learning with traditional approaches: changing practices. British Journal of Educational Technology, 38(2), 337-348. doi:10.1111/j.1467-8535.2006.00630.x

[5] Eraqi, M. I., Abou-Alam, W., Belal, M., \& Fahmi, T. (2011). Attitudes of Undergraduate Students Toward E-Learning in Tourism: The Case of Egypt. Journal of Teaching in Travel \& Tourism, 11(4), 325-348. doi:10.1080/15313220.2011.624397

[6] Hsu, L. (2020). Learning tourism and hospitality subjects with massive open online courses (MOOCs): A cross-sectional and longitudinal study. Journal of Hospitality, Leisure, Sport \& Tourism Education, 100276. doi:10.1016/j.jhlste.2020.100276

[7] Lominé, L. L., (2002). Online learning and teaching in Hospitality, Leisure, Sport, and Tourism: Myths, Opportunities, and Challenges, Journal

[8] Ministry of Culture, S., and T. (2020). Ministry of Culture, Sports and Tourism (2020 April 9) Official Letter No. 1399/BVHTTDL-TCDL: Proposing additional solutions to remove difficulties for the tourism industry affected by the Covid-19 epidemic. https://luatvietnam.vn/chinh-sach/congvan-1399-bvhttdl-tcdl-de-xuat-bo-sung-giai-phap-thao-go-kho-khan-cho-nganh-du-lich-182469-d6.html

[9] Mohammadi, H. (2015). Investigating users' perspectives on e-learning: An integration of TAM and IS success model. Computers in Human Behavior. Volume 45, April 2015

[10] Nguyen, T.M. Nghia; Nguyen, T.T. Van \& Tran, H. Tuan (2020). Investigating factors affecting learner's needs of e-learning programs in tourism: Case in the Central Coastal Region of Vietnam. Tourist $2^{\text {nd }}$ Cross-border Conference - Proceedings, 173-187

[11] Penfold, P. 2008). Learning through the world of Second Life: A hospitality and Tourism experience. Journal of Teaching in Travel and Tourism, 8(2), 139-160.

[12] Qteishat M. (2013). Factors influencing the adoption of e-learning in Jorgan: An extended TAM model, European Journal of Business and Management, 5(18), 84-100.

[13] Quang, T. D., Tran, T. C., Tran, V. H., Nguyen, T. T., \& Nguyen, T. T. (2020). Is Vietnam ready to welcome tourists back? Assessing COVID-19's economic impact and the Vietnamese tourism industry's response to the pandemic. Current Issues in Tourism, 119. doi:10.1080/13683500.2020.1860916

[14] Servage (2005). Strategizing for workplace e-learning: Some critical considerations. Journal of Workplace Learning. 17(5/6304-317

[15] Sigala, M. (2020). Tourism and Covid-19: Impacts and implications for advancing and resetting industry and research. Journal of Business Research, 117, 312-321. DOI: 10.1016/j.jbusres.2020.06.015

[16] Sun, P. C., Tsai, R. J., Finger, G., Chen, Y.Y., \& Yeh, D. (2008). What drives successful e-learning? An empirical investigation of the critical factors influencing learner satisfaction. Computers and Education, 50(4), 1183-1202.

[17] Sun Microsystems Association Report (2007). E-learning framework (Technical white paper). Santa Clara, CA: Sun Microsystems Inc. 